\title{
Research on Income Inequality by Gender in Vietnam
}

\author{
Ho Thi Hoa (Correspondence author) \\ Academy of Finance, 58 Le Van Hien Street,
}

Duc Thang Ward, Bac Tu Liem District, Hanoi 10000, Vietnam

Pham Van Hieu

Hanoi University of Business and Technology, Hanoi, Vietnam

\author{
Nguyen Thanh Thao \\ Academy of Finance, Hanoi, Vietnam
}

Hoang Hai Ninh

Academy of Finance, Hanoi, Vietnam

Le Thi Thuy

Academy of Finance, Hanoi, Vietnam

Received: May 15, 2020 Accepted: July 30, 2020 Online published: August 16, 2020

doi:10.5296/ijhrs.v10i3.17538 URL: https://doi.org/10.5296/ijhrs.v10i3.17538

\begin{abstract}
Inequality of income is considered an important issue of social inequality in general, the subject is mentioned in many studies around the world. Actually, differences in income inequality are considered both causes and resulfs of the other inequalities. In particular, income inequality by gender is matter of special interest to create conditions for both men and women have equal opportunities in economic development - social and human resources development. This study will analyze the income inequality by gender in Vietnam, which propose a number of recommendations in order to implement the goals of equity im the distribution of income and work towards equality by gender in Vietnam in the future.
\end{abstract}

Keywords: income inequality, gender, Vietnam 


\section{The Urgency of the Study}

Apparently, income inequality arises when there are disparities between individuals, groups in society or between countries in the distribution of wealth, or income (Fletcher Michael A, 2013). Gender income inequality is the issue that has been mentioned by many people when studying income inequality in general. The appearance of gender income inequality is not only one of the causes of poverty but also a major hindrance to the development process. Societies with large and long-lasting gender inequalities often have to pay for poverty, malnutrition, sickness and other misery to a greater extent. Moreover, income inequality between the sexes hinders the development of equality that causes inefficiency in the use of resources in society. In fact, income inequality occurs in many countries, especially developing countries. The main cause of this situation stems from the idea of "respect men than women" in society of many countries as well as the gender distribution of labor in different professions. In societies with high gender equality, economic growth will be effective for reducing poverty levels (Nguyen Thi Nguyet, 2007).

Over the past few years, Vietnam economy has been prospering with a relatively high GDP growth rate. However, this process has widened the income gap between the population groups, especially the income gap between genders. This has a significant effect on improving the income status and economic position of labor groups by gender.

Actually, Vietnam has been influenced by the concept of "respect men and disrespect women" for a long time, which is the cause of gender inequality in income. In recent years, the viewpoint of socio-economic development of Vietnam in the period of 2016-2020 refers to focusing on "perfecting socialist-oriented market institutions." The State uses institutions, resources, regulating tools, distribution and redistribution policies to develop culture, implement democracy, progress and social justice; ensure social security, gradually improve social welfare, look after, improve the lives of all people, and narrow the gap between rich and poor "(Vietnam Communist Party Document, 2016). On that basis, gender equality in income goals is also of great interest in Vietnam. The study of gender income inequality in Vietnam not only helps to effectively allocate resources in society, create equal opportunities in income distribution, but also contributes to promoting economic growth.

\section{Literature Review}

Income is defined as an incentive for workers to strive to improve economic efficiency. Definitely, improving the income of population groups will enable everyone to have equal opportunities in life - called social justice (World Bank, 2001). However, income inequality, especially income inequality by gender always exists in society, and in any country. Income inequality by gender is the difference between the income of male and female workers despite having the same characteristics of capacity and labor productivity (Nguyen Thi Nguyet, 2007). A lack of awareness of gender issues means limiting women's access to productivity and employment resources, thereby reducing the overall labor productivity of the economy (UNDP, 2019). Actually, leaving high gender inequality will have a negative impact on income per capita and the benefits associated with improving the quality of life of people in society (World Bank, 2001). On the other hand, ensuring gender equality in income, 
helping to liberate labor, making use of manpower and making labor market become healthier will be significant factors contributing to economic growth (Nguyen Thi Nguyet, 2007). .

In reality, gender inequality is influenced by many factors, of which the first one is education. Opportunity to access to education by different gender has affected workers' income, especially in poor countries and low-income countries (World Bank, 2001). With the same view, Klasen and Stephan (2002), Bandiera and Natraj (2013) also claim that women with lower education level reduces the average human capital, which indirectly affects income growth, thereby has negative influence on growth in general. Baliamoune et al. (2015) refer to the two gender inequality indicators: the gap in the enrollment rate of primary education from females to males and the gap in the enrollment rate of secondary education from females to males. The estimated results indicate that gender inequality in primary and secondary education has a statistically significant negative impact on income, especially in North African and Middle Eastern countries.

The second factor affecting gender inequality is access to high-income jobs. In other words, this is related to the ability to access a high-paid job position between women and men. In the study of Chantreuil, F., \& Lebon, I. (2015), they argued that the income inequality between women and men in France was mainly related to the difficulties of women to get a well-paid job in both public and private sectors. This is related to the ability to access to a high-paid job position between women and men. Brassard (2004) suggested that there was a difference in wages between men and women in the labor sector, research in food, beverage, textile, garments and glass, ceramics, cement. In addition, regional factors also affect the access to opportunities to increase the income of women and men in the economy (Nguyen Thi Nguyet, 2007).

In Vietnam, many authors have conducted research on income inequality by gender, thereby pointing out some main causes of this phenomenon. Firstly, gender inequality occurs as a result of access to and control over resources in the economy (Vu Hoang Anh, 2010; Luu Hong Minh, 2011). In fact, gender inequality occurs in ethnic groups, such as in Gia Lai and An Giang provinces (Vu Hoang Anh, 2010). Ethnic minority women here have not only fewer assets than men, but also have less access to opportunities to promote their capabilities because of limited social protection of women's rights. On the other hand, the factor affecting gender income inequality in Vietnam can be named as educational attainment. Luu Hong Minh (2011) through the social stratification pyramid in respect to income and expenditure in period of 1990-1999 showed that the most influencing factor in social stratification was the value of production materials - where the level of education is directly proportional to the wealth level. It can be said that the higher education level workers have, the higher income level they will attain. In fact, male workers have a higher income of 33\% than female workers in all occupations. The lowest income gap between men and women is the public sector- at $7 \%$. In developing or low-income countries, gender differences increase income inequality (Nguyen Duy Loi et al., 2014). Finally, the factors of macroeconomic policies affecting women also influence gender equality, opportunities for income enhancement and women's welfare (Nguyen Thi Nguyet, 2007). 
In general, recent studies have shown different factors affecting the change in income inequality by gender. This difference has implications for policy makers to come up with effective solutions to achieve progress and equality for people and society. However, it should be noted that the study of income inequality by gender should be based on the reality of each country and each development period.

\section{Research Method}

This research uses qualitative research methods, evaluations which are synthesized from previous studies. Statistical analysis describes the real situation of income inequality by gender in Vietnam. Data sources are from Vietnam Statistical Yearbook, Vietnam Household Living Standards Survey (VLSS) 2002-2016, Labor and Employment Report 2011 and 2016 of the General Statistics Office of Vietnam. Data from a number of other sources such as UNDP, WB.

\section{Gender Income Inequality in Vietnam}

\subsection{The Real Situation of Income Inequality by Gender in Vietnam}

Vietnam is a country that has undergone dramatic changes from a centrally planned economy to a socialist-oriented market economy. The changes of the economy have greatly affected the achievement of goals of progress and social justice. This is reflected in the improvement of the Human Development Index (HDI) around the world. Vietnam's HDI has still tended to increase recently, in 2014 alone it increased by 7 ranks compared to the previous year. However, compared to other countries in Asia - Pacific, this index of Vietnam tends to be lower. In 1990, the HDI value of Vietnam was $8,1 \%$, which was lower than the average of the East Asia - Pacific region. After that, this gap was also narrowed to 4,7\% in 2008. By 2017, it has expanded to 5,3\% (UNDP, 2019). According to UNDP, this gap occurs due to the fact that other countries in the region get more and more progressive results in human development, especially in the field of education.

In reality, gender inequality is assessed through many indicators. The Gender-related Development Index (GDI) is one of the indicator groups that reflects the disparities in living standards as well as the achievements between men and women of a country. According to a report by UNDP (2019), Vietnam's index and hierarchy of gender development tend to decrease over the years, demonstrating that Vietnam's gender inequality has improved. It is assessed by international organizations that Vietnam is the nation that has had the fastest rate in eliminating gender gap over the past 20 years. Particularly in 2014, Vietnam's Gender Development Index reached 0,308 and ranked 60/146 countries in the world. This contributes to improving indicators related to gender equality, including gender equality in income in Vietnam. However, gender income disparities have been existed in Vietnam in recent years. 
Table 1. Human development index and gender development index of Vietnam and some Southeast Asian countries in 2014

\begin{tabular}{|c|c|c|c|c|}
\hline Year & $\begin{array}{c}\text { Human } \\
\text { Development } \\
\text { Index (HDI) }\end{array}$ & $\begin{array}{c}\text { Change the } \\
\text { ranking of } \\
\text { human } \\
\text { development } \\
\text { index in 173 } \\
\text { countries }\end{array}$ & $\begin{array}{c}\text { Gender } \\
\text { development } \\
\text { index }\end{array}$ & $\begin{array}{c}\text { Gender development } \\
\text { index ranking in 146 } \\
\text { countries }\end{array}$ \\
\hline Vietnam & 0,666 & +9 & 0,330 & 60 \\
\hline Singapore & 0,912 & & 0,088 & 13 \\
\hline Thailand & 0,726 & +1 & 0,380 & 76 \\
\hline Philippines & 0,668 & +7 & 0,420 & 89 \\
\hline Malaysia & 0,779 & & 0,209 & 42 \\
\hline Indonesia & 0,648 & +6 & 0,494 & 110 \\
\hline
\end{tabular}

Source: Human Development Report 2015 - UNDP

Vietnamese female workers account for a high proportion of the labor market. According to the International Labor Organization (2016), the labor force participation rate of Vietnamese women reached $72 \%$, which was higher than the world average of $49 \%$. However, there have been disparities in income between women and men in recent years in Vietnam. This is reflected in the 2002 statistics that the average monthly income of women was $85 \%$ of that of men. In the period of 2009 - 2016, the average monthly income of women was still $10 \%$ lower than that of men. This difference is equivalent to about 30 USD on the total salary of less than 200 USD per month (nhandan.com.vn)

In reality, the income level of women depends heavily on wage employment. However, the average income from wage jobs of women has increased, from VND 1464 thousand per month in 2007 to VND 5304 thousand per month in 2016, which was still lower than that of men. Particularly in 2016, the income rate from wage work of women was11.9\%, which was lower than that of men.

Table 2. Force and income from wage employment by gender in Vietnam

\begin{tabular}{|l|c|c|c|c|c|c|c|}
\hline \multicolumn{2}{|c|}{ Targets } & $\mathbf{2 0 0 7}$ & $\mathbf{2 0 1 0}$ & $\mathbf{2 0 1 3}$ & $\mathbf{2 0 1 4}$ & $\mathbf{2 0 1 5}$ & $\mathbf{2 0 1 6}$ \\
\hline \multirow{2}{*}{ 1. Labor force structure (\%) } & Male & 50,8 & 51,4 & 51,4 & 51,3 & 51,6 & 51,6 \\
\cline { 2 - 8 } & Female & 49,2 & 48,6 & 48,6 & 48,7 & 48,4 & 48,4 \\
\hline \multirow{2}{*}{$\begin{array}{l}\text { 2. The rate of employed labour } \\
(\%)\end{array}$} & male & 50,8 & 51,6 & 51,4 & 51,2 & 51,5 & 51,5 \\
\cline { 2 - 8 } & Female & 49,2 & 48,4 & 48,6 & 48,8 & 48,5 & 48,5 \\
\hline \multirow{2}{*}{$\begin{array}{l}\text { 3. Average income from a monthly } \\
\text { wage of a wage worker (thousand } \\
\text { dong) }\end{array}$} & male & 1464 & 2668 & 4287 & 4645 & 4925 & 5304 \\
\cline { 2 - 8 } & Female & 1280 & 2297 & 3884 & 4235 & 4430 & 4739 \\
\hline
\end{tabular}


Source: Labor and Employment Report 2011, 2016 - General Statistics Office, Vietnam

When comparing the income of male and female workers in Vietnam with the same level of education, living area, age and ethnic group, the wage difference is even higher, up to $15,4 \%$ in 2011. That means women received wages which was $15,4 \%$ lower than men's wage with the same education, ethnic group, and age. This disparity has decreased in recent years, from $15,4 \%$ in 2011 to $12,6 \%$ in 2014 (World Bank, 2018).

Considering the gender income of self-employed workers, basically in most self-employed groups, the average income of men is higher than that of women. Only in the retail sector in 2016, the income of women was 1,11 times higher than that of men.

Table 3. Average monthly income per capita of men and women by self-employed industry (Unit: VND 1,000)

\begin{tabular}{|c|c|c|c|c|c|c|c|}
\hline $\begin{array}{c}\text { About } \\
\text { properties }\end{array}$ & Year & \multicolumn{7}{|c|}{ Self-employed trades } \\
\cline { 3 - 8 } & & $\begin{array}{c}\text { Agro } \\
\text { Industry }\end{array}$ & $\begin{array}{c}\text { Forestry } \\
\text { Industry }\end{array}$ & $\begin{array}{c}\text { Aquatic } \\
\text { products }\end{array}$ & $\begin{array}{c}\text { Public } \\
\text { Industry }\end{array}$ & $\begin{array}{c}\text { Build } \\
\text { up }\end{array}$ & $\begin{array}{c}\text { Wholesale and } \\
\text { retail }\end{array}$ \\
\hline \multirow{5}{*}{ Male } & 2006 & 144,8 & 5,8 & 23,9 & 35,8 & 4.1 & 56,9 \\
\cline { 2 - 8 } & 2008 & 225,6 & 7,8 & 33,1 & 53,2 & 5,9 & 88,7 \\
\cline { 2 - 8 } & 2010 & 269,5 & 11,4 & 34,4 & 73 & 10 & 142,1 \\
\cline { 2 - 8 } & 2012 & 382,8 & 15,5 & 49 & 85,6 & 16,6 & 198,3 \\
\cline { 2 - 8 } & 2014 & 438 & 18,3 & 63,3 & 120,9 & 17,6 & 264,4 \\
\cline { 2 - 8 } & $\mathbf{2 0 1 6}$ & $\mathbf{4 8 7 , 1}$ & $\mathbf{2 1 , 1}$ & $\mathbf{7 3 , 8}$ & $\mathbf{1 4 1 , 2}$ & $\mathbf{3 4 , 9}$ & $\mathbf{3 2 8 , 1}$ \\
\hline \multirow{5}{*}{ Female } & 2006 & 83,2 & 2,4 & 11,2 & 30,9 & 1,1 & 81,8 \\
\cline { 2 - 8 } & 2008 & 118,7 & 3,9 & 16,7 & 40,7 & 3 & 117 \\
\cline { 2 - 8 } & 2010 & 130,3 & 4,5 & 18,8 & 57 & 7,8 & 166,7 \\
\cline { 2 - 8 } & 2012 & 186,3 & 6,9 & 23,3 & 66,7 & 6,7 & 221,5 \\
\cline { 2 - 8 } & 2014 & 211,7 & 6,4 & 27,8 & 96 & 10 & 257,8 \\
\cline { 2 - 8 } & $\mathbf{2 0 1 6}$ & $\mathbf{2 2 2 , 7}$ & $\mathbf{7 , 1}$ & $\mathbf{2 8 , 3}$ & $\mathbf{9 9 , 8}$ & $\mathbf{1 6 , 8}$ & $\mathbf{3 6 6 , 7}$ \\
\hline
\end{tabular}

Source: data on Vietnam household living standards 2016

Gini coefficient is used to indicate income inequality across different population groups. It is based on income of men and women per capita in the period of 2002 - 2016 in Vietnam and tends to increase. In particular, the Gini coefficient of women tends to increase faster than the male group. The average Gini coefficient of male for the whole period 2002 - 2016 was at 0.4, while the average female Gini coefficient was at 0,51. Considering the relative inequality, this is a high income inequality when according to the World Bank (2001) the Gini coefficient should be less than 0,4. Comparing in the period of 2002 - 216, the Gini coefficient of the female group increased from 0,4 in 2002 to 0,66 in 2016, meaning that the absolute increase was 0,26 , or about $65 \%$ in the last 14 years. This shows that the inequality of income among female groups is increasing rapidly in Vietnam. This can be explained by the disparity in access to income generation opportunities among women, especially between urban and rural areas. For the male group, the income inequality was less fluctuated. In 2016, it increased by 
only 0,01 , or about $2,17 \%$ compared to 2002 .

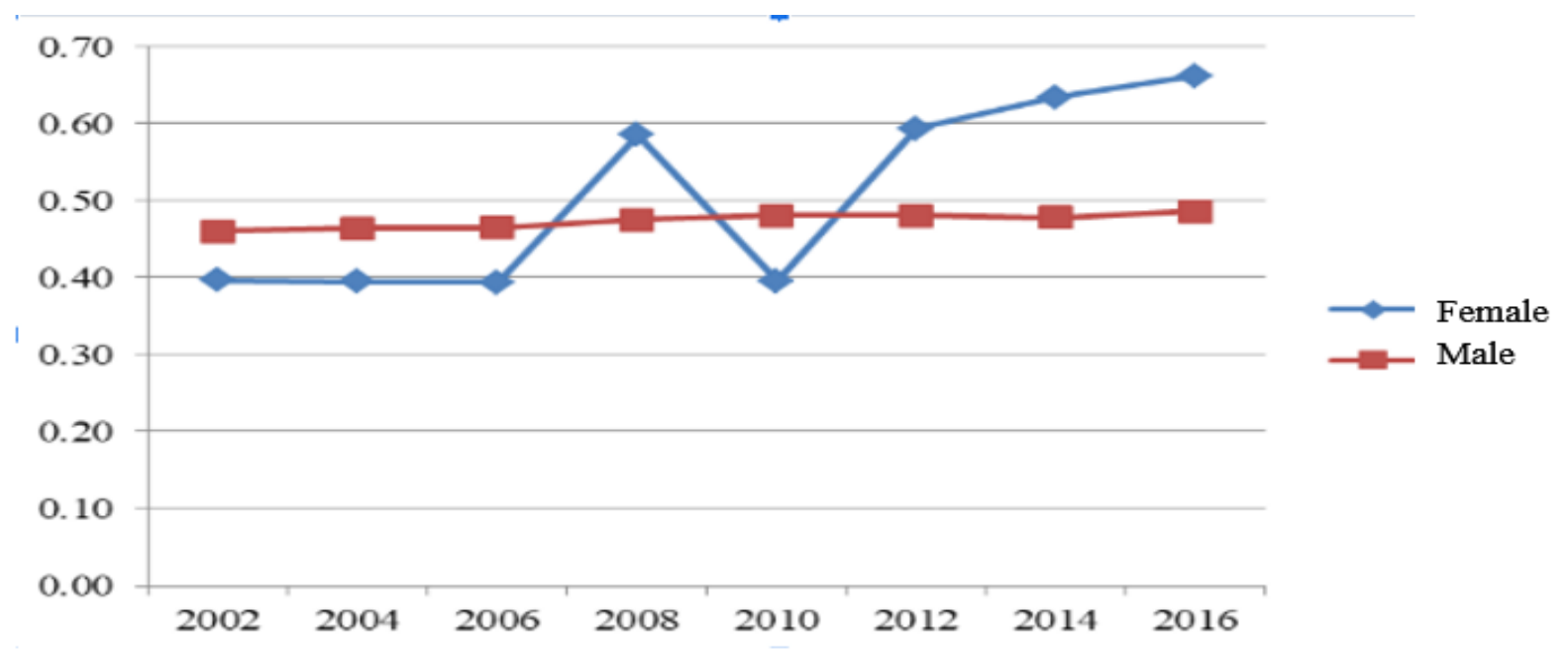

Graph 1. Gini coefficient by gender of Vietnam

Source: Author calculated from the 2016 Vietnam household living standards survey

In addition, female workers also face difficulties in accessing basic social services such as health and education. Female employees working in industrial zones and export processing zones are migrant workers. As a result, migrant workers and their children have difficulty accessing basic social security services. Specifically, up to $71 \%$ of migrant workers do not have access to public health services at their destination. And $21,2 \%$ of children between the ages of 6 and 14 years old according to their parents living at the destination did not go to school. This is an alarming number of children who are unable to access the education system. Only $7,7 \%$ of migrant children attend public kindergartens, and $12 \%$ of migrant children attend public kindergartens. The remaining depend on kindergartens, private kindergartens or family daycare groups. This has a significant impact on the income of female workers, most of whom find it difficult to balance household work and income generating jobs (Source: Oxfam Vietnam, 2015).

Thus, inequality of income in labor may reflect a combination of factors including differences in educational attainment, expertise, work experience and other causes together with the discrimination. Actually, each aspect of this gender inequality needs to be addressed completely.

\subsection{Factors Affecting Gender Income Inequality in Vietnam}

\subsubsection{Employee Characteristics}

The characteristics of employees are related to issues of age, marital status, health status of workers. These issues affect workers' income (Nguyen Thi Nguyet, 2007).

Vietnam is undergoing a process of changing the age structure of the population with a rapidly increasing proportion of the population in working ages (15-64), the proportion of the child population (0-14 years) is declining and the proportion of the population and the number of elderly people (population 65 years and older) is increasing rapidly. The process of 
changing the population age structure by gender (male and female) also takes place in the direction of increasing the proportion of the population in working age of male and female (Source: Development Strategy Institute, Ministry of Planning and Investment, 2014)). In the period of 2017 - 2016, the proportion of male population in working age increased from $50,8 \%$ to $51,6 \%$, the proportion of female population decreased from $49,2 \%$ to $48,4 \%$. Besides, according to Vietnamese regulations, the working age of men is from 15 to 60 years, while the working age of women is from 15 to 55 years (General Statistics Office, 2016). By gender, the welfare for males often lasts longer than for females (about 3-5 years). This leads to a higher income for men than for women in the economy.

In 2016, the young labor force (15-24 years) nationwide accounted for 13,8\% of the total labor force (equivalent to 7,5 million people). In which, the proportion of young women participating in economic activities is lower than that of men in urban and rural areas and 6 socio-economic regions of Vietnam. The highest difference is found in the Mekong River Delta, where ratio of men are $18,2 \%$ which is higher than that of females. In the "family labor" group, female workers are still the majority (about 65\%), this group of workers is easy to lose their jobs and hardly receive any kind of social insurance (Labor and Employment Report of the General Statistics Office, 2016).

Women often face barriers to care for families, preventing them from having better jobs to increase their income after marriage (Nguyen Thi Thanh Huyen et al, 2018). When accepting a young female employee, business owners are often afraid of 6 months maternity leave. Many businesses force female employees to sign an annex to their labor contracts to not become pregnant during the first 2 years of employment. As a result, some businesses prefer to recruit men even though their ability to work is inferior to that of women. On the subject of wages, the pay for female workers is lower than for male workers. This is not necessary because business owners intentionally pay female workers less than men doing the same job. The main reason is that women have to take care of children and are responsible for housework, so the workdays are not as many as that of men.

In 2016, the average number of working hours for male workers was 46,1 hours / week, while the average number of working hours for female workers was 43,6 hours / week (Source: Labor and Employment Report made by the General Statistics Office, 2016). In Vietnam, women spend 35 hours a week doing housework compared to 21 hours for men. Uneducated women spend 9 hours a day doing unpaid work in the family (World Bank, 2018). These family responsibilities need to be equivalent to a full-time job, thus limit women's access to the labor market. In fact, jobs that require long hours of work are often far away (take a long travel time) or have a non-regular working time frame that may not be compatible with family responsibilities. Therefore, it limits job options made by women. This can also lead women to the tragedy of having low-paid jobs in return for benefits of the policy which are friendlier for family such as family leave and social insurance (Chowdhury et al., 2018). .

In addition, health issues are also factors affecting the income of female workers. Currently, it is not too difficult to find job advertisements, the published salary shows the difference between men and women. It is often believed that men will work longer, more efficiently and 
more effectively than women. A range of prejudiced thoughts can be listed such as: Men are harder and more persistent than women with longer working hours per day, or may work overtime on weekends; they have better physic and mental for work than women, and can tolerate more stressful and negative thought. They also have ambitious to pursue career goals and attain a higher position than women. (Source: CareerBuilder.vn )

\subsubsection{Education}

There are still many challenges in education and human resource development. The proportion of employed workers who have never attended school accounts for 3,4\% of the total employed population, of which women account for a higher proportion than men (accounting for 61,4\%). Data show that, at lower levels of education, there are more females than males. Over time, at the high education level, there are more men than women. Statistically, the percentage of women who have never attended school in 2001 was $70,6 \%$, and was $61,4 \%$ in 2016 . The ratio of women with technical and professional qualifications in 2016 was $18 \%$, while this rate for men was $23 \%$.

Table 4. Percentage of Vietnam's labor force by education level (unit:\%)

\begin{tabular}{|c|c|c|c|c|c|c|}
\hline Targets & \multicolumn{3}{|c|}{ In 2011 } & \multicolumn{3}{c|}{ In 2016 } \\
\hline Academic level & Male & Female & \% Female & Male & Female & \% Female \\
\hline Not going to school yet & 1,8 & 3.1 & 70,6 & 2,6 & 4,3 & 61,4 \\
\hline Not graduated & 6,6 & 10 & 67,2 & 9,4 & 11,3 & 53 \\
\hline Primary school graduate & 18,7 & 22,2 & 61,7 & 22,8 & 23,4 & 49,2 \\
\hline School graduation base & 26,6 & 25,2 & 56,4 & 29,5 & 30,3 & 49,2 \\
\hline $\begin{array}{c}\text { High school graduation } \\
\text { secondary }\end{array}$ & 19,9 & 18,4 & 55,8 & 12,7 & 12,7 & 48,5 \\
\hline $\begin{array}{c}\text { Having technical and } \\
\text { professional qualifications }\end{array}$ & 26,4 & 21,1 & 60,5 & 23 & 18 & 42,4 \\
\hline
\end{tabular}

Source: Labor and Employment Report 2011, 2016 - General Statistics Office, Vietnam

Gender inequality in education is partly due to women being closely associated with the role of taking care of the family, and women having significantly lower education levels than men. Women tend to be more concentrated in secondary education and have lower education level than men.

Not only do female workers suffer a lot from the division of jobs or the heavy responsibilities in each family, but even children also experience discrimination among boys and girls. According to data from the Vietnam Statistical Yearbook (GSO, 2016), the differential in sex ratio at birth is constantly increasing. If this situation is prolonged, it will seriously affect the gender balance in the population. Accordingly, if in 2011, the sex ratio at birth in our country was 111,1 / 100, in 2016 this rate reached 113,4 / 100 (equivalent to every 100 girls born, more than 113 baby boys were also born). If the sex ratio continues to increase and spread as it is today, the problem of gender imbalance in Vietnam in the next 20-25 years will be very 
serious. This also significantly affects women's access to basic social services, especially in education, when Vietnam is strongly influenced by feudal and Confucian ideas. The thought of "respect men and disdain women" is ingrained, taking root in many generations' lives. In reality, discriminations against women persist in families and to the wider community. Girls are often expected to cede higher education to their brothers and tend to drop out of school to take care of their families. Women also focus on the notion that in order to maintain family well-being, women should have lower education than their husbands (Institute of Socioeconomic, 2015).

\subsubsection{Industry Characteristics}

The characteristics of the occupational group include factors such as labor industry, qualification, work experience, working organization (Nguyen Thi Nguyet, 2007).

The sex selection in some economic sectors is quite clear. In 2011, there were sectors with a low proportion of female employees in the industry, such as: "Warehouse transportation" with 9,3\%, "Construction" with only 9,7\%, "Production and electricity, gas, steam and air conditioning distribution" with $16.9 \%$. In contrast, there are sectors with majority of females such as: "Working as hired laborers in households" with female workers accounting for 90,6\%, "Education and training" and "accommodation and eating service" with female workers accounting for nearly $70 \%$ of the industry's total employment (Source: General Statistics Office, 2011). In 2015, statistics showed that female workers tended to concentrate more than men in agriculture and services. Nearly $52 \%$ of agricultural workers were women, compared to about $48 \%$ men. About $55 \%$ of self-employed non-farm workers were women, compared to $45 \%$ who are men. These two types of jobs have low labor productivity, and average income is lower than the minimum wage. In addition, these jobs are also a source of risky income due to bad weather and are easily affected by small changes in prices or buying trends of consumers. These jobs require workers to work long hours and in difficult conditions. Women also account for a large share of unpaid household work in agriculture (Source: World Bank, 2018). In 2016, the industries that used more female workers than men were still personal services and sales $(61,9 \%)$, unskilled labor $(52,1 \%)$, agriculture $(40,4 \%)$, while female workers as leaders accounted for a modest proportion $(26,1 \%)$ (Source: General Statistics Office, 2016).

Vietnamese female workers are currently working in a lower condition than male workers, with only $49 \%$ of female workers in the wage group having labor contracts with employers, which is lower than $58,8 \%$ of men. In addition, the foreign invested sector is the relatively high paid sector in Vietnam, with $73,91 \%$ of male workers working under labor contracts, while this proportion of female workers is $67,67 \%$ (Source: World Bank, 2018)

Vietnam has also recorded many efforts towards gender equality goals in the political field and in the policy making process. This is reflected in the guidelines for socio-economic development. The position and role of women has gradually been affirmed and made great contributions to the cause of national development, as the number of female delegates participating in the People's Councils at all levels has increased over the years. The proportion of women elected to the National Assembly of Vietnam has fluctuated around 25\% 
between 2007 and 2016. While the percentage of women in the legislative bodies is relatively higher than in the elected bodies. However, because there is still a perception that if women are leaders, the effectiveness will not be as high as that of men, so women in high positions are relatively limited, not compatible with the proportion of women in the total population.

Table 5. Proportion of women participating in the People's Council at all levels (Unit:\%)

\begin{tabular}{|l|l|l|l|l|}
\hline \multirow{2}{*}{ Levels } & \multicolumn{2}{|c|}{ Period 2004 - 2011 } & \multicolumn{2}{c|}{ The period of 2011-2016 } \\
\cline { 2 - 5 } & \multicolumn{1}{|c|}{ Female } & male & \multicolumn{1}{c|}{ Female } & male \\
\hline Province level & 23,80 & 76,20 & 25,17 & 74,83 \\
\hline District & 23,20 & 76,80 & 24,62 & 75,38 \\
\hline Commune & 20,10 & 79,90 & 21,71 & 78,29 \\
\hline
\end{tabular}

Source: Ministry of Home Affairs, Institute of Science and State Organization, National Assembly, term XIII, 2011

\subsubsection{Geographic Region}

In recent years, there has been an increase in Vietnam's labor force in urban areas, but our labor force has still concentrated in rural areas (accounting for $67.8 \%$ in 2016). The proportion of workers without labor contracts is lower for women than for men and for rural areas (Source: General Statistics Office, 2016).

The diversity of occupations has particularly supported the division of labor by gender, which is evident in urban areas. Labors in rural areas, mainly work in the agricultural sector, so career options are limited, and gender discrimination in the profession is not much. In urban areas, women focus on trading, light industry (especially textiles), public offices and social services. Meanwhile, men often dominate in skill-intensive industries such as mechanics, manufacturing and mining (Nguyen Thi Nguyet, 2007). This also leads to the difference in income between women and men.

Table 6. Male and female labor force by urban and rural residence

\begin{tabular}{|c|c|c|c|c|c|}
\hline \multirow{3}{*}{ Year } & \multirow{2}{*}{$\begin{array}{c}\text { Residence } \\
\text { residence / Region }\end{array}$} & \multirow{2}{*}{$\begin{array}{c}\text { Force } \\
\text { labor } \\
\text { in thousands) }\end{array}$} & & \multicolumn{3}{|c|}{ Proportion (\%) } \\
\cline { 4 - 6 } & & 51398,4 & 100 & 100 & 100 \\
\hline 2011 & Country & 15251,9 & 29,7 & 29,9 & 29,5 \\
\cline { 2 - 6 } & City & 36146,5 & 70,3 & 70,1 & 70,5 \\
\cline { 2 - 6 } & Countryside & 54445,3 & 100 & 100 & 100 \\
\hline \multirow{2}{*}{2016} & Country & 17449,9 & 32,1 & 32,2 & 31,9 \\
\cline { 2 - 6 } & City & 36995,4 & 67,9 & 67,8 & 68,1 \\
\cline { 2 - 6 } & Countryside & \multicolumn{3}{|c|}{ Female } \\
\hline
\end{tabular}

Source: Labor and Employment Report 2011, 2016 - General Statistics Office of Vietnam

\subsubsection{Environment and Policy Related to Income and Gender}

Equality in work means equality of rights, responsibilities, opportunities, treatment and evaluation for each employee regardless of their legal gender (Nguyen Thi Nguyet, 2007). 
Recognizing the important role of women in contributing labor capacity to promote economic development, Vietnam has defined the equality of women and men over the years. Article 24 of the Vietnamese Constitution states that "Women have equal rights to men in all activities: politics, economy, culture at home and in society". Accordingly, the Law on Gender Equality was passed by the National Assembly of the Socialist Republic of Vietnam, XII, on November 29, 2006, and took effect from July 1, 2007. This Law provides principles gender equality in all fields of social and family life, measures to ensure gender equality, responsibilities of agencies, organizations, families and individuals in the implementation of gender equality. The goal is to eliminate gender discrimination, create equal opportunities for men and women in socio-economic development and human resource development, towards substantive gender equality between men and women and establish, strengthen cooperation and support relationships between men and women in all areas of social and family life.

However, there are still factors that prevent women from entering into formal employment and equally benefiting from work. Compared with the level of development of the country, Vietnam has many labor policies that "protect" women workers such as pension, childbirth, restrict or prohibit women from doing hard and dangerous job. For example, while labor policies to protect pregnant women are absolutely necessary and for the benefit of women and society, comprehensive protection policies should not create high cost to encourage employers to hire, recruit, train or promote women. However, the Labor Code does not permit the employment of women working in fields considered hazardous to women's health. Furthermore, the law should not restrict the choice of women's professions.

In addition, in general, laws related to gender issues have not been paid much attention by people, namely the Law on Gender Equality, the Law on Marriage and Family, and the Law on Prevention of Domestic Violence. Around 15\% and 30\% of people have never heard of the aforementioned laws. More than two thirds of people have only heard of the names of the law and have a rough understanding of them. Only $3 \%$ to $6 \%$ of people said that they understood these laws well (Social Development Research Institute, 2015).

\subsubsection{Group of Other Factors}

Gender inequality leads to inadequacies in women's access to basic social services, which in turn affects the income generation opportunities for female workers. According to the survey results of the Institute for Social Development Studies (2015), more than $20 \%$ of the women who participated in the survey did not work at the time of the survey due to family care, which is larger in comparison with $2 \%$ of men. Moreover, among working people, women are more concentrated in agriculture or in the informal sector. As a result, many women have to pay for social insurance and health insurance themselves. The survey results show that only $1 \%$ of people working in the private sector and about $5 \%$ to $6 \%$ of people working in the informal sector have social insurance, and less than half of these two groups have health insurance. Clearly, women's access to social security and welfare has been greatly limited, including the benefits of pregnancy and childbirth.

Besides health factors, consumption needs are also factors affecting income. Workers must find higher-paying jobs to meet the consumption needs of themselves and their families, 
while those with lower consumption needs are more likely to be satisfied with moderate-income jobs. A quantitative study by Nguyen Thi Nguyet (2007) shows that expenditure per capita and square of this expenditure value also shows the inverse U-shaped relationship between salary and expenditure. The results show that the greater the expenditure demand, the higher the salary is. This effect of women is higher than that of men, and the difference of this effect on wages between men and women increases over time in Vietnam.

Apparently, inequalities in access to means of production, social status, and property ownership also affect women's income. Owning and co-owning the family's most valuable assets play an important role in balancing the power relationship between couples. However, nearly half of the women do not own residential land and only one fifth of women own a home or residential land. By contrast, more than half of the men are the sole owner of residential land or home. Men also often owns the most valuable assets, including production facilities and transportation. In fact, limited ownership of assets reduces women's access to credit and investment opportunities ... (Social Development Research Institute, 2015). In addition, women also face problems with domestic violence, and are victims of human trafficking, labor exploitation, etc. According to statistics from the national survey on domestic violence, $58 \%$ of women ever suffer at least one type of violence and on average one in three women experience violence (United Nations in Viet Nam, 2014).

As a result, each of these factors contributes differently to the change in gender inequality in labor income. This difference will have implications for policymakers to achieve equality and progress for people and society in Vietnam.

\subsection{General Assessment of Gender Income Inequality in Vietnam}

\subsubsection{Achievements}

Previous studies have also shown that gender income inequality is happening in most countries around the world. The statistics also indicate that Vietnam's gender inequality of income is not too serious compared to other countries in the region and to the average of the world. Nevertheless, in order to reduce the level of inequality in general and gender inequality in particular, with certain efforts, Vietnam has made a lot of progress in implementing policies to create gender equality, thereby enabling women to increase income and improve their lives. This was reflected in the increase in women's income in the period of 2002 - 2016. The Government has issued many policies to support women to access to resources in the economy and social policies to be able to increase income and improve life.

\subsubsection{Limitations and Causes}

Firstly, the income level of women in Vietnam has been improved over the years, but the income gap between men and women still occurs when women have significantly lower education levels than men. Women are often disrupted in school due to financial difficulties, housework obligations, pregnancy and childcare. Especially in rural areas, remote areas, and among ethnic groups, these issues have created barriers for female workers in the process of working, striving and devoting. 
Secondly, the industry structure has not yet made full use of the labor force of women, and has not yet been able to make use of human resources as well as labor liberation (Tran Thi Van Anh and Le Ngoc Hung, 2000). Actually, investment in changing occupational structure which is suitable for female workers has not been effective

Thirdly, the implementation of the Gender Equality Law still has many issues that need to be addressed for women. The liberation of women seems to be limited to what the new social mechanism brings, not yet deeply embedded in family life. In families, gender inequality still persists like not recognizing the proper role of women, the division of labor in the family is not reasonable, there are still discrimination issues between men and women, violence against women is limited but still happening, etc. Especially for the majority of poor women in rural areas, ethnic minority women often can not be able to go to school so they cannot access social progress. Women in these areas have little "voice" in the family. In addition to doing housework, taking care of children, etc, they also have to do farming, work for other people, run small business, etc to earn extra income for their families. Sometimes, women still suffer from domestic violence, being abused by their husbands, their husbands' families, etc., but those women still accept to do so and not free themselves.

The main reason is because the society still has prejudices about the role and position of women in the family and society, due to the thought of "patriarch of a man in the family", the thought of "gender prejudice", and so on.

Fourthly, there is still the view that "man is the breadwinner". Traditional gender roles and traditional gender stereotypes still prevail in the perception of many people at all levels of society. "More women than men believe that the husband is the breadwinner and the person who makes decisions about important family issues. More women than men believe that a woman's duty is to look after children and family members" (Social Development Research Institute, 2015). While both men and women report that they have fairly equal participation in decision making on most family issues. Most families report that men have the decisive voice in terms of important cases related to housing, land and expensive asset purchases, while women are often responsible for the problems of everyday life in Vietnamese society.

\section{Conclusion}

Based on the analysis of current situation and factors affecting gender income inequality in Vietnam, there are many factors affecting the income gap of men and women such as: education level, skills or characteristics of workers, employment, geographic region, access to means of production, and the impact of state policy in addressing gender inequality. In recent years, although there have been many efforts to improve the income and life of women to reduce gender inequality in Vietnam, there are still many difficulties to reduce the level of gender inequality in general and income inequality by gender in particular. First of all, Vietnam needs to change its long lasting stereotypes on the subject of the perspective "respect men more than women", and simultaneously creates more opportunities for women to be equal in work. Projects that enable women and men to perform jobs that are considered to be of another gender and help them to renew their traditional roles need to be carried out, thereby improving equality between men and women to meet strategic gender needs (also 
known as meeting gender interests)

\section{References}

Baliamoune - Lutz, M., \& McGillivray, M. (2015). The impact of gender inequality in education on income in Africa and the Middle East. Economic Modeling, 47, 1-11. https://doi.org/10.1016/j.econmod.2014.11.031

Bandiera, O., \& Natraj, A. (2013). Does gender inequality hinder development and economic growth? World Bank Res. Obs., 28(1), 2-21. https://doi.org/10.1093/wbro/lks012

CareerBuilder.vn

Caroline Brassard. (2004). Wage and Labor Regulation in Vietnam within the Poverty Reduction Agenda. Policy and Society, 23. https://doi.org/10.1016/S1449-4035(04)70032-6

Chantreuil, F., \& Lebon, I. (2015). Gender contribution to income inequality. Economics Letters, 133, 27-30. https://doi.org/10.1016/j.econlet.2015.05.009

Chowdhury, I., Elizaveta, P., Hillary, J., \& Aneesh, M. (2018). Gender-based employment division in Vietnam Washington, DC: International Bank for Reconstruction and Development / International Bank for Reconstruction and Development.

Communist Party of Vietnam. (2016). The 12th National Conference of Representatives Congress. Central Party Office, Hanoi.

Cunningham, W., Alidadi, F., Buchhave, H. (2018). Vietnam's Future Jobs: The Gender Dimension: Vietnam's future jobs: the gender dimension (English). Vietnam ABPII Gender Assessment. Washington, D.C.: World Bank Group. https://doi.org/10.1596/30172

Fletcher, \& Michael, A. (2013), Research ties economic inequality to gap in life expectancy . Washington Post.

General Statistics Office - GSO (2016). Labor and Employment Report 2016.

General Statistics Office - GSO (2002,2016), Vietnam household living standard survey 2002, 2016.

General Statistics Office - GSO. (2016). Vietnam Statistical Yearbook 2016.

General Statistics Office. - GSO (2011). Labor and Employment Report 2011.

https://nhandan.com.vn/tin-tuc-xa-hoi/thu-nhap-giua-lao-dong-nu-va-nam-con-chenh-lech-32 9650/

Institute of Development Strategies. (2015). Impact of population age change on Vietnam's economy and policy recommendations. Ministry of Planning and Investment, Vietnam.

Klasen, S. (2002). Low schooling for girls, slower growth for all? Cross-country evidence on the effect of gender inequality in education on economic development. World Bank Econ. Rev., 16(3), 345-373. https://doi.org/10.1093/wber/lhf004 


\section{Macrothink}

International Journal of Human Resource Studies

ISSN 2162-3058 2020, Vol. 10, No. 3

Luu Hong Minh. (2011). Situation of social stratification according to living standards in rural Red River Delta. Ho Chi Minh National Academy of Politics.

Ly Ngoc Nhan. (2014). Evaluation of gender inequality in Vietnam in recent years (2009-2012) - case of Tra Vinh province. Journal of Social Sciences and Humanities, No. 15, September / 20114.

Ministry of Home Affairs - Institute of State Organization Science - National Assembly session XIII (2011). Report on the number and composition of People's Council deputies at all levels for the term $2011-2016$.

Ministry of Labor. (2016). War Invalids and Social Affairs of Vietnam, 2016.

Nguyen Duy Loi et al. (2014). Employment and social protection for female workers in the informal sector in Vietnam. EADN Research Paper, No. 84.

Nguyen Thi Thanh Huyen and Nguyen Thi Ngan. (2018). Income inequality by gender: Theory and reality in Vietnam. Journal of Science and Technology, 19(15), 93-98.

Nguyen, T. N. (2007). Gender equality for workers' income in Vietnam and some policy solutions. Ministry of Planning and Investment Scientific Project, Ministry of Planning and Investment, Vietnam.

Oxfam Vietnam. (2015). Legal and practical barriers for migrant workers in accessing social security.

Social Development Research Institute. (2015). Social factors determining gender inequality in Vietnam. Research results from 2012-2015, Hanoi.

The Gender Equality Law was passed by the National Assembly of the Socialist Republic of Vietnam, term XII, on November 29, 2006, and takes effect from July 1, 2007.

The International Labor Organization. (2016). (https://www.ilo.org/hanoi/Informationresources/Publicinformation/Pressreleases/WCMS_61 9843/lang--vi/index.htm)

Tran Thi Van Anh and Le Ngoc Hung. (2000). Women, Gender and Development. Women's Publishing House, Hanoi.

UNDP (2015), Human Development Report 2015.

UNDP. (2015). Human Development Report 2015, Work for Human Development. New York: The United Nations Development Program

UNDP. (2019). Human Development Report 2019: Inequality in human development in the 21 st century - Not only in terms of income, average and present, Hanoi

United Nations Development Program. (2012). Report on women's participation in leadership and management in Viet Nam. 


\section{Macrothink}

International Journal of Human Resource Studies

ISSN 2162-3058 2020, Vol. 10, No. 3

United Nations in Viet Nam. (2014). From Domestic Violence to Gender-based Violence in Viet Nam: The Link Between Forms of Violence, United Nations Discussion Paper, Hanoi.

Vu Hoang, A. (2010). Report on the status of gender inequality in ethnic minority communities. Syracuse University.

World Bank (2018). The future of Vietnamese employment from a gender perspective, The World Bank Gsroup in Vietnam.

World Bank. (2001). Engendering development: through gender equality in rights, resources, and voice. World Bank Policy Research Report. World Bank and Oxford University Press, Washington, DC and New York.

\section{Copyright Disclaimer}

Copyright for this article is retained by the author(s), with first publication rights granted to the journal.

This is an open-access article distributed under the terms and conditions of the Creative Commons Attribution license (http://creativecommons.org/licenses/by/4.0/). 